\title{
末梢神経麻痺に対する発汗検査法の応用
}

\section{Sweating Test in Evaluation of Peripheral Nerve Paralysis}

\author{
鈴木木茂 $*$
}

Sigeru SUZUKI

\section{緒言}

交感神経機能検查の応用については藤森 1)（1953）の 綜説があり，末梢神経麻痺の皮膚電気抵抗については Glaser2) (1946), 発汗については草場3)（1955）の業績 がある。

私はこれらの業績の追試をかね, 小児の末梢神経麻痺 患者を対象として, 運動並びに知覚神経機能との比較て 扔いて, 交感神経検能の回復状況を観察したので, 症例 等も少なく, かつ検查回数も不充分であるがこっに一括 して報告する。

\section{検查の対象之検查方法}

祫㚗の対象は 5 才から 10 才迄の小児男女 4 例であり， 受傷原因はすべて骨傷によるものであつた。受傷神経は 橈骨神経 3 例, 正中神経 1 例で, 受傷から検査までの期 間泩1日から45 日である。
患览に対する諸検查は麻痺発生後なるべく早期汇且つ 病日の経過を追つて実施する方針をとつたが，種々の都 合で検查筂約を受け，検查回数沬 1 人 3 回から 5 回迄 にとぞまつた。

検查項目としては運動神経機能については筋電図検查 を, 知覚神経機能については痛覚を, 交感神経機能につ いては温熱性発汗検查を行つたが，䏩查法の大要は次の 通りである・な和これらの検查の場合反対側の健康部を 対照とし，その成績を比较するようにした。

(1) 筋電図検查：增幅器は 2-channel 万能装置（三

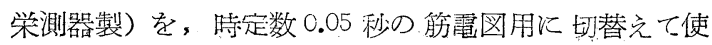
用し，同心型針電極を用い，記録は毎回ブラウン管で観 察しながら横河電磁オッシログラフの Vibrator H K 接続して行つた.

(2) 痛覚検查：刺針を用い:

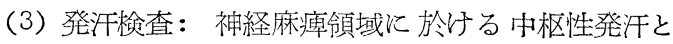

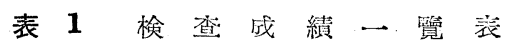

\begin{tabular}{|c|c|c|c|c|c|c|c|c|c|c|}
\hline 㾌 例 & 性 & (别) & $\begin{array}{l}\text { 受 智 } \\
\text { 神 経 }\end{array}$ & & $\begin{array}{l}\text { 検查項目 } \\
\text { 病自日 }\end{array}$ & 解 & 図 & 㾸 & 賞 & 発 \\
\hline I & 男 & 10 & 壀 & 高 & $\begin{array}{r}1 \\
54 \\
76\end{array}$ & $\begin{array}{l}\text { Spike } \\
\text { Spike } \\
\text { Norma }\end{array}$ & $\begin{array}{l}\text { 放霉高度減少 } \\
\text { 放電減少 } \\
1 \text { N.M.U. V. }\end{array}$ & $\begin{array}{l}\text { 軽造鈍 } \\
\text { 正 } \\
\text { 正 }\end{array}$ & $\begin{array}{l}\text { 箱 } \\
\text { 常 } \\
\text { 常 }\end{array}$ & $\begin{array}{l}\text { IE } \\
\text { IE } \\
\text { IE }\end{array}$ \\
\hline $\mathbb{I}$ & 男 & 6 & 正 & $1 \mathrm{~s}$ & $\begin{array}{r}2 \\
25 \\
55 \\
80\end{array}$ & $\begin{array}{l}\text { Spike } \\
\text { Spike } \\
\text { Norma } \\
\text { Norma }\end{array}$ & $\begin{array}{l}\text { 放霄高度減少 } \\
\text { 放雪隇少 } \\
1 \text { N.M.U. V. } \\
1 \text { N.M.U. V. }\end{array}$ & $\begin{array}{l}\text { 消 } \\
\text { 消 } \\
\text { 中舵度鈍 } \\
\text { 正 }\end{array}$ & $\begin{array}{l}\text { 失 } \\
\text { 失 } \\
\text { 椞 } \\
\text { 常 }\end{array}$ & $\begin{array}{l}\text { 汗点沉L } \\
\text { 汗点弘 } \\
\text { 正 常 } \\
\text { 正 常 }\end{array}$ \\
\hline $\mathbb{I I}$ & 男 & 5 & 橈 & 霄 & $\begin{array}{l}30 \\
60 \\
90\end{array}$ & $\begin{array}{l}\text { Spike } \\
\text { Spike } \\
\text { Norma }\end{array}$ & 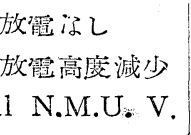 & $\begin{array}{l}\text { 整淡鈍 } \\
\text { 正 } \\
\text { 正 }\end{array}$ & & $\begin{array}{l}\text { 汗点沉し } \\
\text { 汗点流し } \\
\text { 正常 }\end{array}$ \\
\hline IV & 火 & 9 & 梦 & 霄 & $\begin{array}{r}45 \\
75 \\
180 \\
240 \\
300\end{array}$ & $\begin{array}{l}\text { Spike } \\
\text { Spike } \\
\text { Spike } \\
\text { Re-inn } \\
\text { Norma }\end{array}$ & 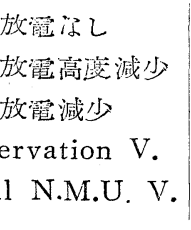 & 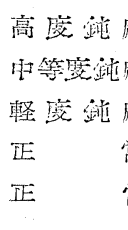 & & 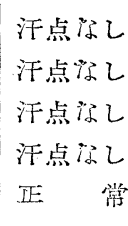 \\
\hline
\end{tabular}

順天堂犬学医学部筑 2 生理学教室

1958 年3 月 17 日受付 
しての温熱性発汗の有無をみるために，患児を室温 $25^{\circ}$ $\mathrm{C}$ から $30^{\circ} \mathrm{C}$ の手術室に入れて発汗を起させ, その発 汗を和田一高垣法 (3\% のョード液を皮膚に塗り, 乾燥 後, ヒマシ油澱粉液を塗布する)で観察した。

\section{検 查 成 績}

個々の成績は表 1 に示されているが，これを検查項目 別にみると，

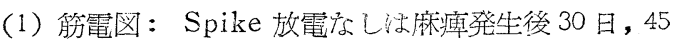
日似, Spike 放電䯩度減少深: 1 日, 2 日, 60 日, 75 日, に, Spike 放電減少法25日, 54 日, 180 日飞, Normal N.M.U. Voltage 汇55日，76日，90日，300日に見ら れた。神経再生を意味する Reinnervation Voltage 240 日に見られた。

(2) 痛覚：消失怯麻疩発生後2日, 25 日に, 高度鈍

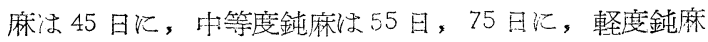
は1 日, 30 日, 180 日纪, 正常沬54日, 60 日, 80 日, 240 日に見られた。

(3) 発汗：汗点心し惊25日, 60 日, 240 日以, 正常 は55日, 90日,300日に見られた。発汗が初めから正 常のものは 1 例むつた。図 1 は暁骨神経麻痺発生後 240 日目汇和外る温熱性発汗の停止を示し, 図2 は橈骨神経 麻㿎発生後 300 日目に括忛る温熱性発汗の出現を示し, 共症例IVの発汗成績を示す。

一般汇筋電図, 痛覚, 発汗の回復過程酒相互関係を見

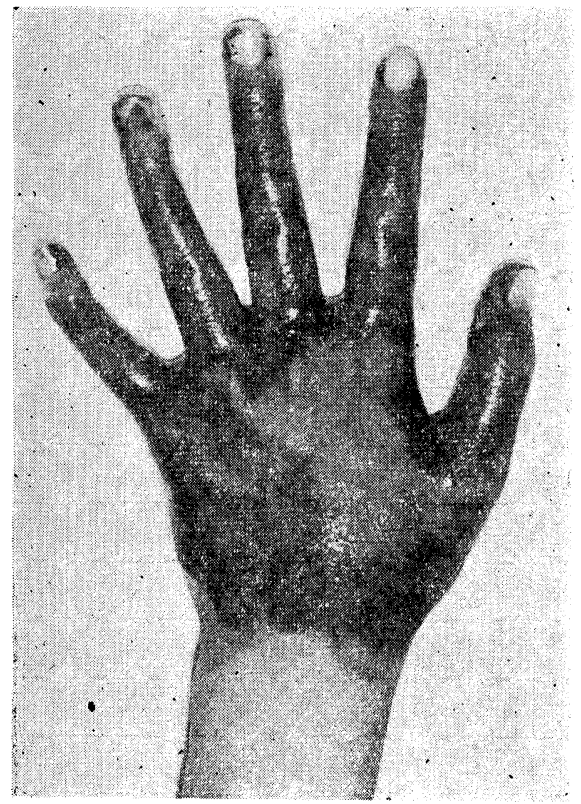

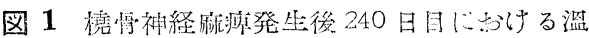
淫性発汗の停止总示す

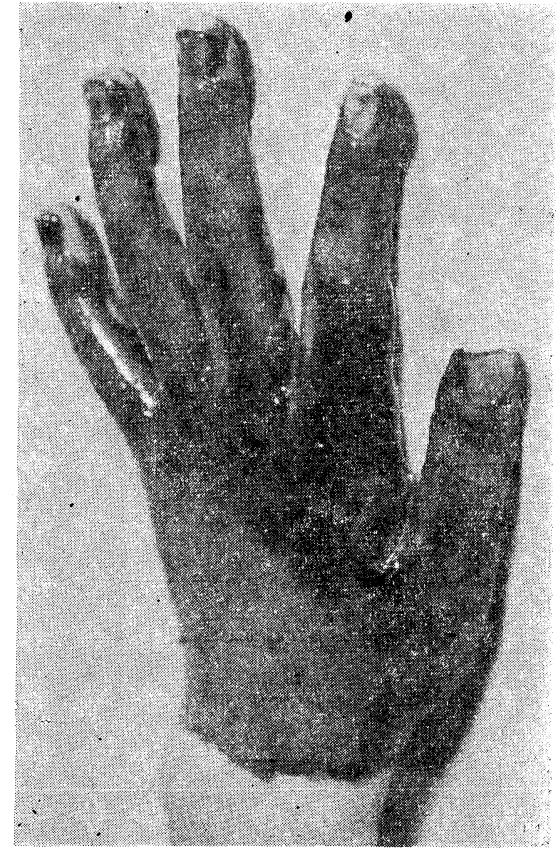

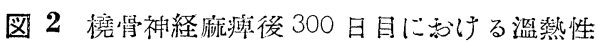
発汗の出現定示す

出すことは出来なかつた。

神経麻痺が一番早く回復した例は 54 日で痛党が，76 日で筇電図が正常化回復し，登汗が最初から正常であつ た、それ比して一番遅く回復した例は 240 日で痛覚 が，300日で筋電龱が正常汇回復し，発汗が 300 日で初 めて正常に回復した。

上記の成績から逆に発汗の状態を絤查のることにより その神経麻瘦の予後を或る程度推測出来ると考光られ る.

末梢神経麻痺の予後を判定する場合に筋電図, 痛党, 発汗の梌查方法法夫々の特長が㸩り，私の少数の症例で はとれらの価值を比較検討することは出来ないが，少く とも小罗では発汗検查が方法も簡単で, 痛及も伴わず, 他覚的に検查出来る点最も適していると思わ机る。

\section{考按}

各種の末梢神経傷害患者 87 例について経過を追つて 運動, 知覚, 皮睢電気抵抗検查法汇よる交感神経機能を 検查した Glaser, Moldover, Hoen 2) は完全な神経切” 断では高抵抗領域は知覚消失領域と一致し, 運動麻瘦の 程应とも併行したが，神経の部分傷害または恢復期には これら 3 者つ間仙必ずしも法則性は認められず，徒つて

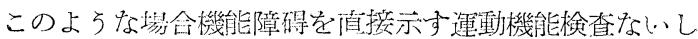


知覚検查汇対して, 抵抗桧查法の臨床応用価值は比較的 低いと述べている。

各種の未梢神経麻痺 7 例につ1.・運動知覚麻疩の経過 と発汗の消長を調べた 草場 3) は発汗の状態を検査する ことによりその神経麻痺の予後を湾淁推測したりまた 手術汇対する適応を判定出来るのではないかと述べてい る.

私の検查成續惢筋電図, 痛覚, 発汗の回復過程㑑互 関係を見出すことが出来なかつたが，発汗と神経麻痺の 予後との間汇或る程度の相互関係が認められ，上記の諸 業績と一致する成績であつた。

筋電困が, 神経一筋系の疾患の診断, 治潦方法の決 定, 治療效果の判定, 予後の推定等就て, 最も大きな 役割を演んじているの神経麻瘏の場合であつて，他の 追従を許さない.新しい検查方法であると加藤 4)（1954） は述べている。

Richter, Katz ${ }^{5}$ (1943) は10名の尺骨神経傷害者に 皮膚電気抵抗検查を応用した結果基き，皮膚電気抵抗 検查によつて末梢神経傷害領域は明磪に劃定でき，これ によれば傷者が無意識の場合汇も神経傷害の診断ができ るばかりでなく，治癒の経過も追及でき，乙かも操作も 簡単であるから実用性の高い良法であると推賞してい る.

以上先人の業績からも末梢神経麻痺の予後を判定する 場合饬等電図, 痛党, 発汗の倹查方法洁夫々の特長があ りそそれらの価値を比較検討することは出来ないが，少 くとも小照の場合には発汗検査が方法も簡単で, 痛及も 伴わず，他覚的汇検査出来る点最も適していると思われ る.
総括

小児の骨傷儿よる末㭘神経麻痺 4 例を対象として, 運 動神経機能並びと知覚神経機能との比蔽に特いて, 交感 神経機能の回復状況を発汗により観察した。

発汗と末梢神経麻瘏の予後との間に或る程度の相互関 係が認められ，小罗の場合には発汗検查法が方法も簡単 で, 痛みも伴わず，他覚的㰸查出来る点最も適してい ると思われる。

終りに本研究に゙当り, 御指導总いただいた順天堂大学

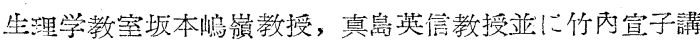

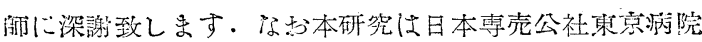
臨枺生理に゙むいて行われたこと总附記します。

\section{文献}

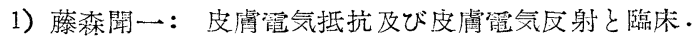
脳 神経， 5 (5) 259-283，(1953).

2) Glaser, G.H., Moldover, J. and Hoen, T.I.: Electrical skin resistance test in evaluation of peripheral nerve injuries. Arch. Neurol. Psychiat. 56, 365 380, (1946).

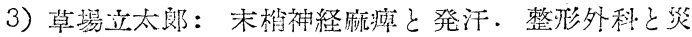
害外科, $\mathbf{5}(1), 29-31,(1955)$.

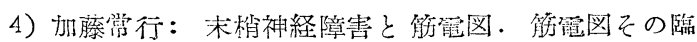
床的応用, 226-238, 永井書店, (1954).

5) Richter, C. P. and Katz, D. T.: Peripheral nerve injuries determined by the electrical skin resistance method. J. A. M. A. 122, 648 651, (1943).

\section{Summary}

In the four cases of the peripheral nerve paralysis of children by osteolesion are observed the recovery syndroms of the sympathetic nerve function together with motor nerve and sensory nerve syndroms.

Of course, the sweating is regarded as a function of sympathetic and important for prognosis.

Especially on the young patients the sweating test established by Masao Wada and T. Takagaki is very convenient in the most cases.

2nd Department of Physiology, Juntendo University, School of Medicine 